ORNL/TM-13582
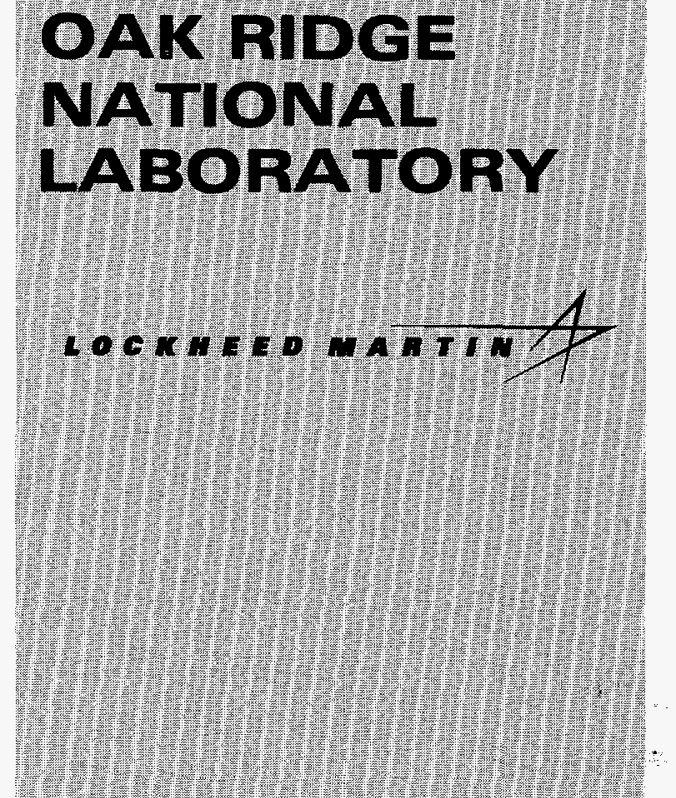

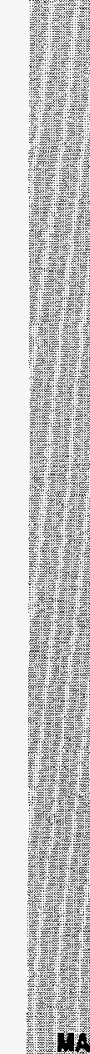

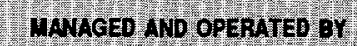

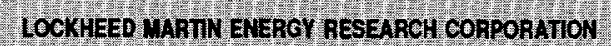
FOTHCUHCOST MES DEP ARHET OF ENERG

\title{
Multi-Weight Isotherm Results for Mercury Removal in Upper East Fork Poplar Creek Water
}

\author{
D. A. Bostick \\ K. T. Klasson
}

RECEIVED

MAR 121998

OSTI 
This report has been reproduced directly from the best available copy.

Available to DOE and DOE contractors from the Office of Scientific and Technical Information, P.O. Box 62, Oak Ridge, TN 37831; prices available from (423) 576-8401, FTS 626-8401.

This report was prepared as an account of work sponsored by an agency of the United States Government. Neither the United States Government nor any agency thereof, nor any of their employees, makes any warranty, express or implied, or assumes any legal liability or responsibility for the accuracy, completeness, or usefulness of any information, apparatus, product, or process disclosed, or represents that its use would not infringe privately owned rights. Reference herein to any specific commercial product, process, or service by trade name, trademark, manufacturer, or otherwise, does not necessarily constitute or imply its endorsement, recommendation, or favoring by the United States Government or any agency thereof. The views and opinions of authors expressed herein do not necessarily state or reflect those of the United States Government or any agency thereof. 


\section{DISCLAIMER}

Portions of this document may be illegible electronic image products. Images are produced from the best available original document. 
D. A. Bostick

K. T. Klasson

Date Published: February 1998

Prepared by

OAK RIDGE NATIONAL LABORATORY

Oak Ridge, Tennessee 37831-6285

managed by

LOCKHEED MARTIN ENERGY RESEARCH CORP.

for the

U.S. DEPARTMENT OF ENERGY

under contract DE-AC05-960R22464 


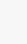




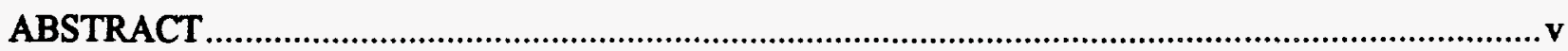

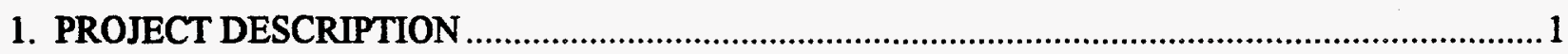

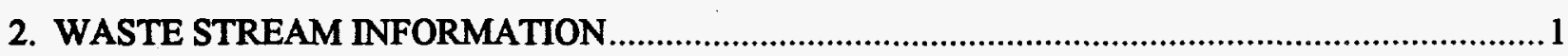

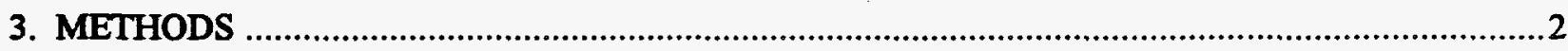

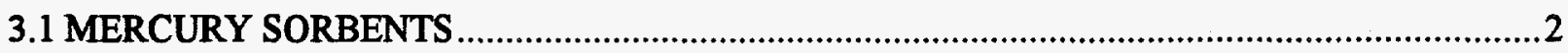

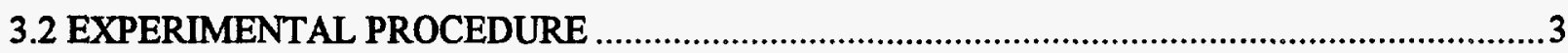

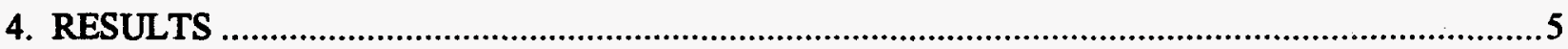

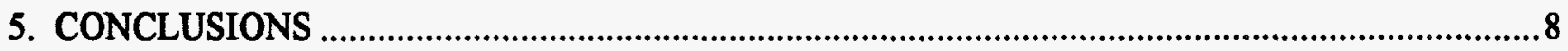

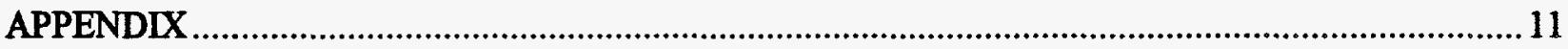

\section{LIST OF FIGURES}

Figure $\quad \underline{\text { Page }}$

1 Isotherm results from multi-weight testing of Ionac SR-3, by Sybron Chemicals, Inc. ...................6

2 Isotherm results from multi-weight testing of Ionac SR-4, by Sybron Chemicals, Inc. ..................6

3 Isotherm results from multi-weight testing of Keyle:X, by SolmeteX ........................................7

4 Isotherm results from multi-weight testing of the Forager Sponge, by Dynaphore, Inc.................. 7

5 Isotherm results from multi-weight testing of Mersorb $1.5 \mathrm{~mm}$, by Nucon International, Inc. ........ 8

\section{LIST OF TABLES}

Table

1 Summary results of isotherm testing. 9

A-1 Multi-weight sorption isotherm for Ionac SR-3, by Sybron Chemicals, Inc.............................. 13

A-2 Multi-weight sorption isotherm for Ionac SR-4, by Sybron Chemicals, Inc............................... 14

A-3 Multi-weight sorption isotherm for Keyle:X, by SolmeteX ............................................... 15

A-4 Multi-weight sorption isotherm for the Forager Sponge, by Dynaphor, Inc............................... 16

A-5 Multi-weight sorption isotherm for Mersorb $1.5 \mathrm{~mm}$, by Nucon International, Inc...................... 17 



\begin{abstract}
Many sorbents have been developed for the removal of mercury and heavy metals from waters; however, the majority of data published to date do not address the removal of mercury to the target levels represented in this project. The application to which these sorbents are targeted for use is the removal of mercury from microgram-per-liter levels to low nanogram-per-liter levels. Sorbents with thiouronium, thiol, amine, sulfur, and proprietary functional groups were selected for these studies.
\end{abstract}

The initial mercury content in the majority of the batch samples was significantly augmented so that the equilibrium concentration was similar to that found in the original stream sample for at least one sample.

Mercury was successfully removed from actual water via adsorption onto Ionac SR-4 (by Sybron Chemicals, Inc.), Keyle:X (by SolmeteX), and Mersorb (by Nucon International, Inc.) resins to levels below the target goal of $12 \mathrm{ng} / \mathrm{L}$. A thiol-based resin (Ionac SR-4) performed the best, indicating that over 200,000 volumes of water could be treated with one volume of resin. The cost of the resin is approximately $\$ 0.24$ per $1000 \mathrm{gal}$ of water. 


\section{PROJECT DESCRIPTION}

The Engineering Development Section of the Chemical Technology Division at Oak Ridge National Laboratory (ORNL) will engage in several activities related to field and laboratory testing of sorbents and chelators for removal of mercury from water.

The work will combine demonstration of commercially (or near commercially) available ion-exchange or sorption resins. During batch (results presented here) and short kinetic studies, the best available commercial sorbent will be tested. Later, the best-performing and most cost-effective sorbents will be tested long term. Samples will be collected and analyzed for total mercury by an off-site laboratory.

\section{WASTE STREAM INFORMATION}

Two Department of Energy sites at ORNL and the Oak Ridge Y-12 Plant have large water streams with low concentrations of mercury. The Nonradiological Wastewater Treatment Plant (NRWTP) at ORNL is operated by waste management staff, and the Upper East Fork Poplar Creek (UEFPC) Characterization Area at the Y-12 Plant is managed by environmental restoration personnel. Both of these streams are regulated by National Pollutant Discharge Elimination System permits from the state of Tennessee. The flows are large - $350 \mathrm{gal} / \mathrm{min}$ (NRWTP) and $1700 \mathrm{gal} / \mathrm{min}$ (UEFPC) - and contain low levels of mercury in the range of 50 to $1000 \mathrm{ng} / \mathrm{L}$. The desired treatment goal is 12 to $19 \mathrm{ng} / \mathrm{L}$. The UEFPC receives water from various sources, some of which have already received limited mercury treatment; whether the surface water in the creek or waters bound for the creek will be treated in this study will be decided through discussion with environmental restoration staff at the Y-12 Plant. Some of the identified sources have flows in the range of 1 to $10 \mathrm{gal} / \mathrm{min}$, with mercury concentrations of $2-40 \mu \mathrm{g} / \mathrm{L}$. The NRWTP is currently using two activated carbon columns in series, each operating at a flow rate of 0.1 bed volumes (BV) per minute. The target level of $19 \mathrm{ng} / \mathrm{L}$ cannot be met with the current system, and a potential replacement sorbent is sought. The following results are from isotherm experiments conducted with UEFPC water (Outfall 200). 


\section{METHODS}

\subsection{MERCURY SORBENTS}

Many sorbents have been developed for the removal of mercury and heavy metals from waters; however, the majority of data published to date do not address the removal of mercury to the target levels represented in this project. The application where these sorbents are targeted for use is in the removal of mercury from microgram-per-liter levels to low nanogram-per-liter levels. Sorbents with thiouronium, thiol, amine, sulfur, and proprietary functional groups were selected for these studies.

Ionac SR-3, by Sybron Chemicals, Inc., is a commercial macroporous polystyrene/divinylbenzene resin with (iso)thiouronium functional groups. This sorbent has been found to bind ionic mercury(II), methyl mercury, and elemental mercury and cannot be regenerated. It performs best at $\mathrm{pH}$ values between 0 and 6. At higher $\mathrm{pH}$, the thiouronium group is converted into a thiol group. The cost of SR-3 is approximately $\$ 12 / \mathrm{L}$ (SR-3). A similar resin is Purolite S-920 by the Purolite Company (\$24/L).

Ionac SR-4, by Sybron Chemicals, Inc., a macroporous ,weakly acidic polystyrene/divinylbenzene cation resin with thiol functional groups, is commercially available at a cost of about $\$ 14 / \mathrm{L}$. It can be used at $\mathrm{pH}$ values ranging from 1 to 14 . The recommended flow rate is $0.3 \mathrm{BV} / \mathrm{min}$. Other materials with similar functionality are Duolite GT-73, by Rohm and Haas ( $\$ 35 / \mathrm{L}$ ), and SAMMS (Self-Assembled Mesaporous Mercaptan Support), a newly developed inorganic thiol resin by Pacific Northwest National Laboratory (PNNL) that is not yet commercially available. The predicted cost is $\$ 50 / \mathrm{L}$. PNNL has presented data indicating that elemental and organic mercury may be adsorbed by SAMMS. In general, the thiol resins can sorb only mercury(II) ions.

Keyle:X, by SolmeteX, is polystyrene/divinylbenzene resin coated with a proprietary polymer with sulfur-based functional groups. Keyle: $X$ is a mercury-specific resin that operates at high flow rates ( 0.2 to $2 \mathrm{BV} / \mathrm{min}$ ). It is recommended that the water be pretreated with chlorine to $1-2 \mathrm{mg} / \mathrm{L}$ to ensure that the mercury is in the ionic state. The cost is $\$ 126 / \mathrm{L}$.

The Forager Sponge, by Dynaphore, Inc., is an open-cell cellulose sponge incorporating an aminecontaining polymer that has selectivity for both cationic and anionic species of mercury and other heavy metals. It has the advantage of being a very porous compactible sponge; thus, column capacity can easily be adjusted by altering the packing density. The sponge can be pretreated with acid or base to change functionality (anionic versus cationic). The cost is $\$ 5 / \mathrm{L}$. 
Mersorb LW, Mersorb 3, and Mersorb $1.5 \mathrm{~mm}$ (by Nucon International, Inc.) are commercial carbons impregnated with sulfur. The only difference between the three is particle size. Since the sorption is dependent upon precipitation of the sulfide, competing metal ions are those that form strong sulfide bonds. The cost is $\$ 5 / \mathrm{L}$.

\subsection{EXPERIMENTAL PROCEDURE}

The batch sorption experiment was conducted with water collected from East Fork Poplar Creek at Outfall 200 at the Y-12 Plant. The water was collected after a $1-\mu \mathrm{m}$ filter.

The batch isotherm samples were run in 250 -mL I-Chem bottles with Teflon-lined closures. Sorbent masses were approximately $0.225,0.45,2.25$, and $4.5 \mathrm{~g}$; the solution volume was roughly $150 \mathrm{~mL}$. The bottles were mixed on a Labquake $B$ shaker for $24 \mathrm{~h}$ at room temperature $\left(22\right.$ to $24^{\circ} \mathrm{C}$ ). The aqueous phase was separated by using a Whatman Autovial syringe filter with a $0.45-\mu \mathrm{m}$-pore membrane filter and transferred to a clean 125-mL I-Chem bottle prior to refrigeration, shipment, and analyses. The sample set included several quality control samples:

1. a process blank containing approximately $150 \mathrm{~mL}$ nanopure water (sample 8),

2. a stream sample that was not processed but was immediately refrigerated after collection (sample 9),

3. a 150-mL stream sample that had been fully processed but without sorbent (sample 7), and

4. a duplicate of a sorbent-treated stream sample (sample 3 is a duplicate of sample 2).

Additionally, loss of mercury to the glass walls of the sample containers was estimated by including three (samples 2, 7, and 11) of the original 250-mL sample bottles in the sample set. These three bottles were rinsed with a minimal amount of water to remove adhered sorbent; $50 \mathrm{~mL}$ nanopure water was then added to each bottle and shaken. No preservative was added to any of the samples before shipment. Analysis of mercury was carried out by Frontier Geosciences, Inc. The samples were oxidized with 1 vol \% $0.2 \mathrm{~N}$ $\mathrm{BrCl}$ and analyzed by $\mathrm{SnCl}_{2}$ reduction, dual gold amalgamation, and cold vapor atomic fluorescence detection.

Six samples in the batch sorption experiment were spiked with mercuric(II) nitrate to augment the total mercury content; two water samples were not spiked with mercury. The sorbents were used as received from the manufacturers, except in the case of Keyle:X, which was washed in nanopure water according to directions. 
The sorption capacity was calculated using three different methods to account for various losses during the treatment procedure. In the first estimate of $K_{d}$ (equal to sorption capacity divided by equilibrium concentration), the blank mercury level (sample 8) was subtracted from reported analytical results to calculate a net final mercury concentration in each of the treated samples. The initial mercury concentration was assumed to be the net mercury content of the unprocessed, refrigerated sample (sample 9), plus any spike added to the sample. The $K_{d}$ for each treated sample was then calculated as follows:

$$
K_{d}=\frac{\left([H g]_{9}^{\text {net }}+[H g]_{i}^{\text {spike }}-[H g]_{i}^{\text {not }}\right) \times L_{i}}{[H g]_{i}^{\text {net }} \times W_{i}}
$$

In the second estimate of $K_{d}$, loss of mercury was attributed primarily to sorption on equipment walls. A sorption ratio for the "walls" was calculated by assuming that the initial net [ $\mathrm{Hg}]$ was represented by the untreated stream sample (sample 9) that was immediately refrigerated (plus any spike). The final $[\mathrm{Hg}]$ was assumed to be that of the processed sample (plus spike) that did not contain sorbent (sample 7):

$$
K_{d}^{\text {walls }}=\frac{\left([\mathrm{Hg}]_{9}^{\text {net }}+[\mathrm{Hg}]_{7}^{\text {spike }}-[\mathrm{Hg}]_{7}^{\text {net }}\right) \times L_{i}}{[\mathrm{Hg}]_{7}^{\text {net }}}
$$

The $K_{d}$ for each sample was then calculated as follows:

$$
K_{d}=\frac{\left([H g]_{9}^{\text {net }}+[H g]_{i}^{\text {spike }}-[H g]_{i}^{\text {net }}\right) \times L_{i}-K_{d}^{\text {walls }} \times[H g]_{i}^{\text {net }}}{[H g]_{i}^{\text {net }} \times W_{i}}
$$

The third method to estimate $K_{d}$ was to assume that each sample lost a fixed fraction of mercury as a result of volatilization and sorption onto equipment walls. The fractional loss was calculated based on the ratio of mercury concentration in the processed sample without sorbent (sample 7) to that of the refrigerated sample (sample 9) plus the amount of mercury initially added to the sample. The initial mercury concentration was then multiplied by the correction factor, $c f$, to determine $K_{d}$ :

$$
c f=\frac{[H g]_{7}^{\text {not }}}{[H g]_{9}^{\text {net }}+[H g]_{7}^{\text {spike }}}
$$


and

$$
K_{d}=\frac{\left\{c f \times\left([H g]_{9}^{\text {net }}+[H g]_{i}^{\text {spike }}\right)-[H g]_{i}^{s p i k e}\right\} \times L_{i}}{[H g]_{i}^{\text {net }} \times W_{i}}
$$

\section{RESULTS}

All process blanks (nanopure water) indicated a mercury content of $<2 \mathrm{ng} / \mathrm{L}$ (see Appendix). This could be an existing contamination in the water or could come from the equipment used in the experiments. The initial mercury content in the majority of the batch samples was significantly augmented so that equilibrium concentration was well above the blank level and was similar to that found in the original stream sample for at least one sample. The three methods for calculating $K_{d}$ gave almost identical results regardless of correction method used. It is also evident from the results that Ionac SR-4, Keyle:X, and Mersorb were able to remove mercury in the creek water to values below $12 \mathrm{ng} / \mathrm{L}$ (target goal).

The isotherm plots are shown in Figs. 1 through 5 , in which the sorbent loading has been plotted as a function of the equilibrium concentration. The sorbent loading was calculated using the second correction method described above. Several results are evident. The experiment conducted with the thiouronium-based resin shows significant scatter in the data. One possible explanation may be that the sorbent partially broke down in the neutral water, producing a thiol-based resin. Some of the data in the low-concentration region appear scattered (see Figs. 2 and 5). Without additional experiments, it is difficult to determine which of the points are suspicious. The fact that the points do not seem to fall on the straight line may indicate that the form of the mercury in solution does not match that of the spiked solution. It is very possible that a fraction of the mercury is present in the elemental form $\left(\mathrm{Hg}^{\mathrm{g}}\right)$, which may be converted to $\mathrm{Hg}^{+}$in the presence of larger amount of $\mathrm{Hg}^{2+}$, which is found in the spiking solution. Ionic mercury is predominantly the sorptive species. This would explain why there was more mercury in solution at equilibrium in some unspiked experiments than in some spiked experiments. 


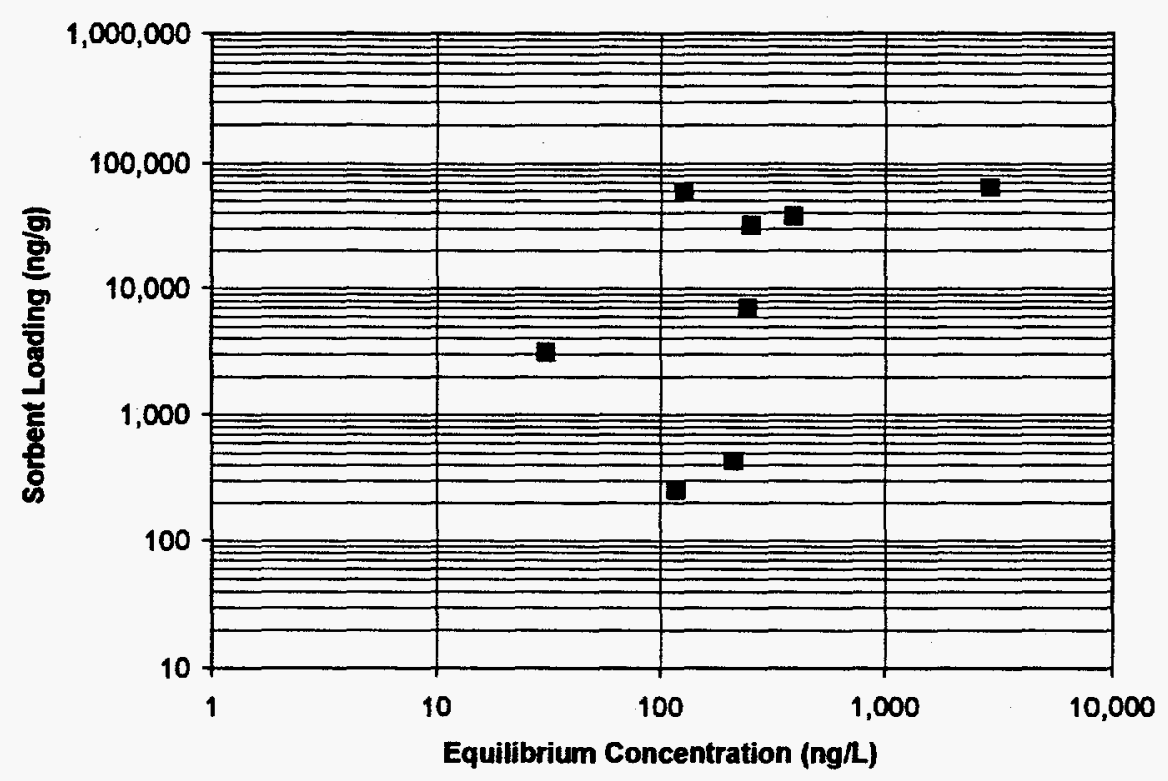

Fig. 1. Isotherm results from multi-weight testing of Ionac SR-3, by Sybron Chemicals, Inc.

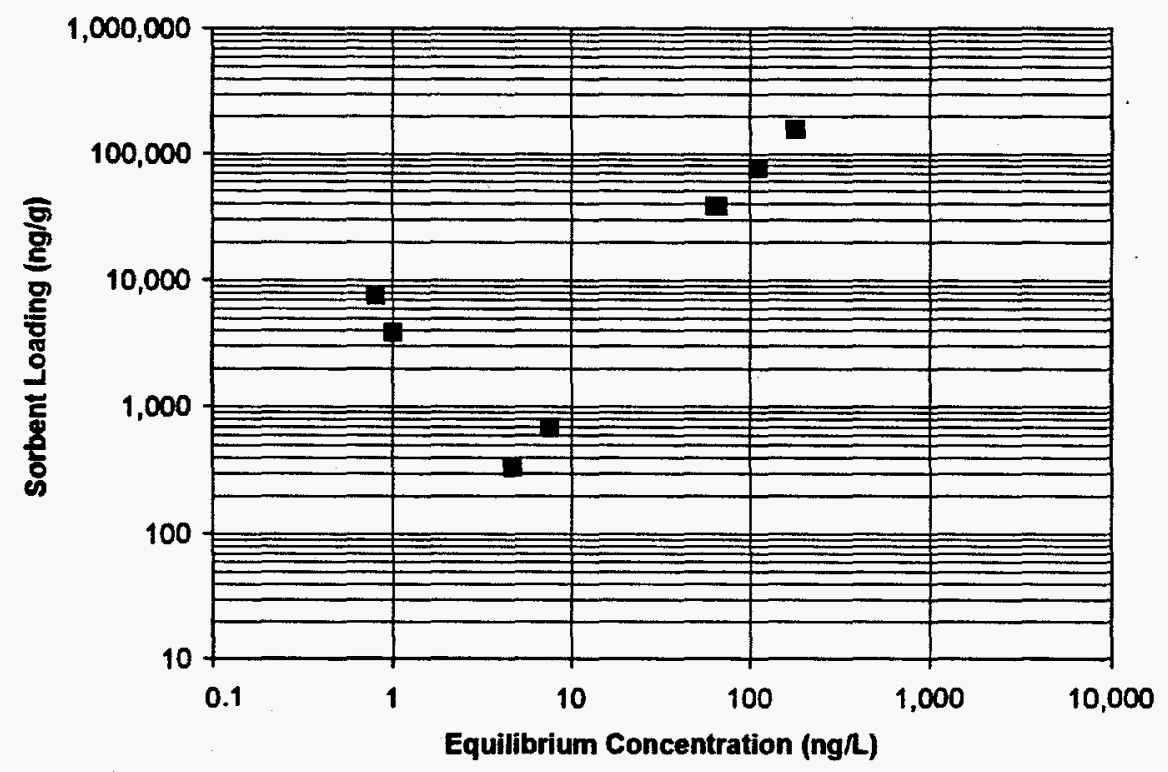

Fig. 2. Isotherm results from multi-weight testing of Ionac SR-4, by Sybron Chemicals, Inc. 


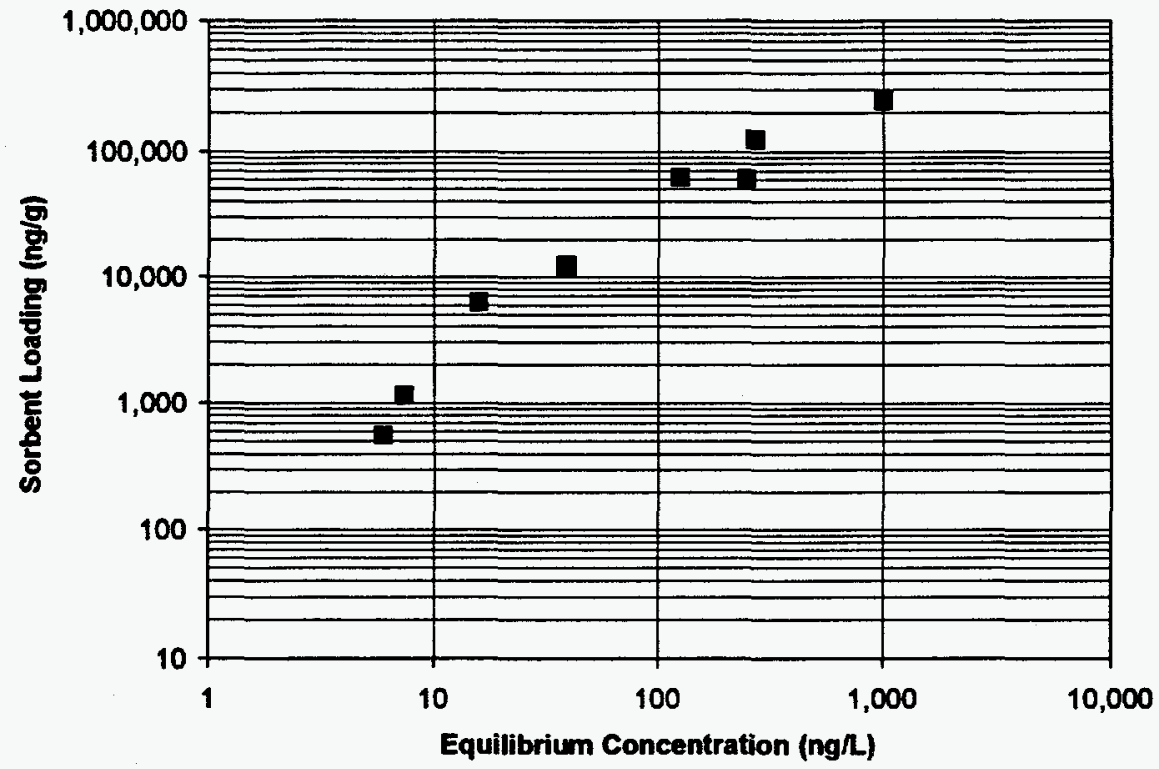

Fig. 3. Isotherm results from multi-weight testing of Keyle:X, by SolmeteX.

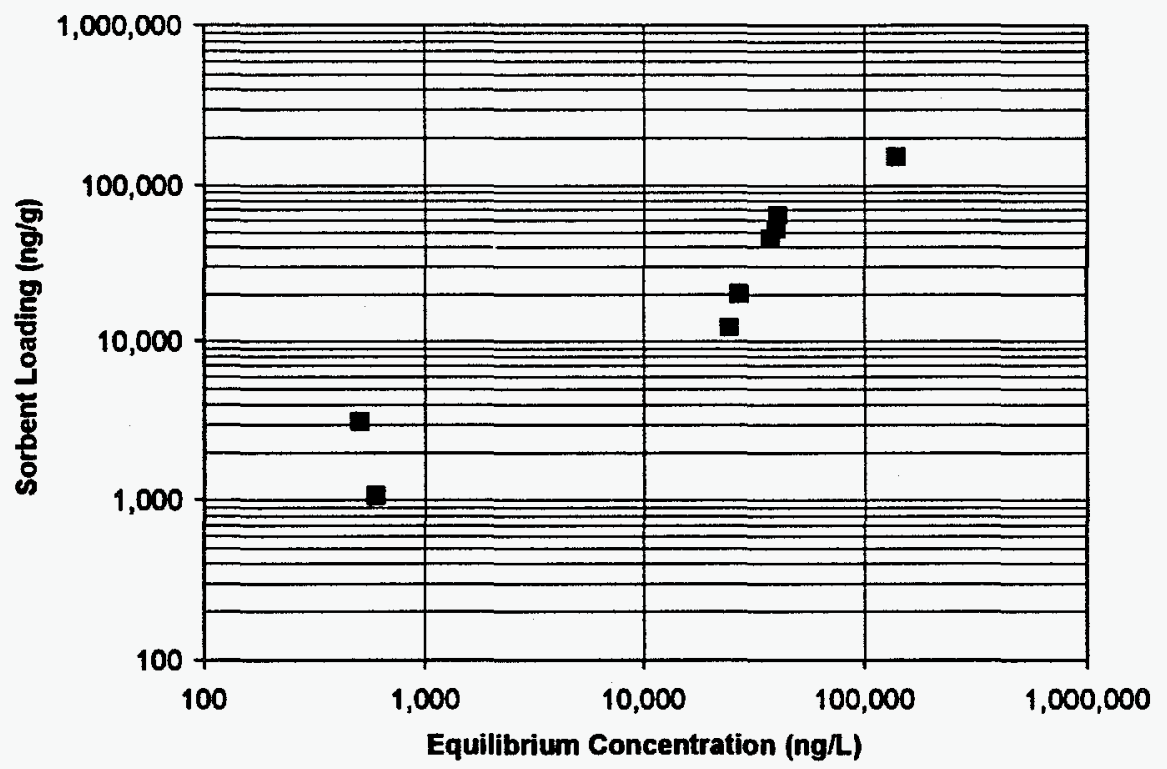

Fig. 4. Isotherm results from multi-weight testing of the Forager Sponge, by Dynaphore, Inc. 


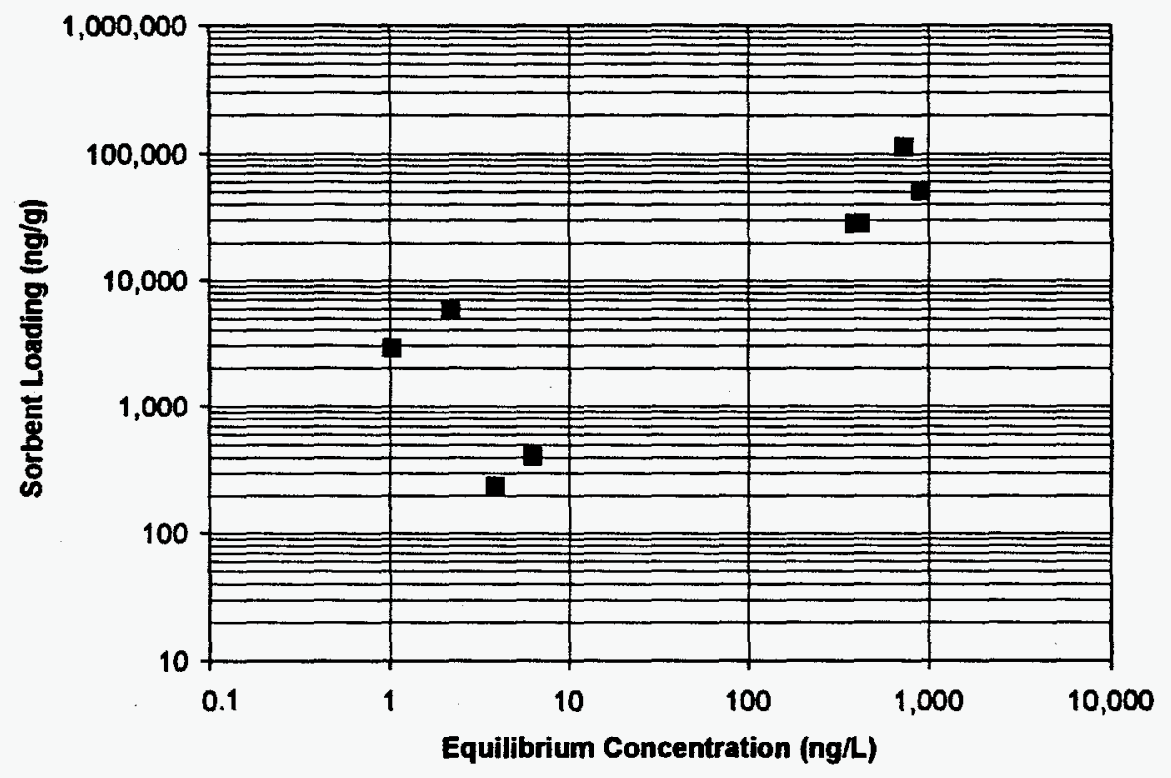

Fig. 5. Isotherm results from multi-weight testing of Mersorb $1.5 \mathrm{~mm}$, by Nucon International, Inc.

The results are summarized in Table 1 for treatment of a 1000-ng/L stream. As noted, the thiol-based resin (Ionac SR-4) performed much better than all others. The results indicate that $16,700 \mathrm{~L}$ of Outfall 200 water can be treated for $\$ 1$ in resin cost. This corresponds to a cost of approximately $\$ 0.24 / 1000$ gal water. The flow at Outfall 200 is approximately 2.5 million gallons per day; thus, the average daily cost for the resin would be about $\$ 600$.

\section{CONCLUSIONS}

Mercury was successfully removed from actual water via adsorption onto resins to levels below the target goal of $12 \mathrm{ng} / \mathrm{L}$. A thiol-based resin (lonac SR-4) performed the best, indicating that over 200,000 volumes of water could be treated with one volume of resin. The cost of the resin is approximately $\$ 0.24$ per 1000 gal of water. 
Table 1. Summary results of isotherm testing

\begin{tabular}{|c|c|c|c|}
\hline Sorbent & $\begin{array}{c}K_{d}{\text { (dry basis })^{a}} \\
(\mathrm{~L} / \mathrm{kg})\end{array}$ & $\begin{array}{c}K_{d}{\text { (bed basis })^{b}}^{\left(\mathrm{L} / \mathrm{L}_{\mathrm{BV}}\right)} \\
\end{array}$ & $\begin{array}{c}K_{d}(\text { cost basis })^{c} \\
(\mathrm{~L} / \$)\end{array}$ \\
\hline $\begin{array}{l}\text { Sybron Chemicals, Inc. } \\
\text { Ionac SR-3 (thiouronium) }\end{array}$ & 50,000 & 26,700 & 2,200 \\
\hline $\begin{array}{l}\text { Sybron Chemicals, Inc. } \\
\text { Ionac SR-4 (thiol) }\end{array}$ & $500,000^{d}$ & 235,000 & 16,700 \\
\hline $\begin{array}{l}\text { SolmeteX, Inc. } \\
\text { Keyle:X (proprietary) }\end{array}$ & 250,000 & 67,700 & 540 \\
\hline $\begin{array}{l}\text { Dynaphore, Inc. } \\
\text { Forager Sponge (amine) }\end{array}$ & 3,000 & $270^{\mathrm{e}}$ & $54^{\circ}$ \\
\hline $\begin{array}{l}\text { Nucon International, Inc. } \\
\text { Mersorb } 1.5 \mathrm{~mm}\end{array}$ & 70,000 & 39,500 & 7,900 \\
\hline \multicolumn{4}{|c|}{${ }^{a}$ Calculated as sorbent capacity (ng mercury/kg dry sorbent) $\div[1000$ (ng mercury $/ \mathrm{L}$ water) $]$. } \\
\hline \multicolumn{4}{|c|}{${ }^{b}$ Calculated as $\left[K_{d}(\right.$ dry basis $\left.)\right] \times(1-$ moisture content $) \times[$ bulk density $(\mathrm{kg} / \mathrm{L})]$} \\
\hline \multicolumn{4}{|c|}{${ }^{c}$ Calculated as $\left[K_{d}\right.$ (bed basis $\left.)\right] \div\left[\operatorname{cost}\left(\$ / L_{\mathrm{BV}}\right)\right]$} \\
\hline${ }^{d}$ Extrapolated value. & & & \\
\hline
\end{tabular}



APPENDIX

DETAILS OF BATCH EXPERIMENTS 

Table A- 1. Multi-weight sorption isotherm for Ionac SR-3, by Sybron Chemicals, Inc.

\begin{tabular}{|c|c|c|c|c|c|}
\hline Sample bottle & $\begin{array}{l}\text { Dry sorbent } \\
\text { weighta } \\
\text { (g) }\end{array}$ & $\begin{array}{l}\text { Liquid volume } \\
\text { (mL) }\end{array}$ & $\begin{array}{c}\text { Mercury spike } \\
\text { (ngh) }\end{array}$ & $\begin{array}{l}\text { Equilibrium } \\
\text { concentration } \\
\text { (ng/) } \text { gross }\end{array}$ & $\begin{array}{l}\text { Equilibrium } \\
\text { concentration } \\
\text { (ng/L) })_{\text {not }}\end{array}$ \\
\hline$\overline{\text { SR3-1B }}$ & 0.1867 & 166.12 & 73,937 & 2,906 & $2,904.7$ \\
\hline SR3-2B & 0.3789 & 168.66 & 71,501 & 255 & 253.7 \\
\hline SR3-3B & 0.3751 & 170.89 & 83,037 & 392 & 390.8 \\
\hline SR3-4B & 0.3754 & 173.60 & 125,428 & 129 & 127.7 \\
\hline SR3-5B & 1.8781 & 173.13 & 75458 & 246.3 & 245 \\
\hline SR3-6B & 3.7529 & 170.38 & 68,323 & 32.29 & 30.99 \\
\hline SR3-7B & 0 & 171.47 & 71,739 & 72,338 & 72,337 \\
\hline SR3-8B & 0 & 168.92 & 0 & 1.30 & 0 \\
\hline SR3-9A & 0 & 250 & 0 & 677.6 & 676.3 \\
\hline SR3-10B & 0.1876 & 174.7 & 0 & 213.3 & 212 \\
\hline SR3-11B & 0.3762 & 170.6 & 0 & 119.0 & 117.7 \\
\hline \multicolumn{4}{|c|}{ SR3-9A duplicate } & 665.2 & 663.9 \\
\hline \multicolumn{4}{|c|}{ SR3-9A spike (2,020 ng/ Hg added) } & $2,706.4$ & $2,705.1$ \\
\hline \multicolumn{4}{|c|}{ SR3-9A spike duplicate (2,020 ng/ $\mathrm{Hg}$ added) } & $2,797.1$ & $2,795.8$ \\
\hline SR3-2A bottle & & 50 & & 32,214 & \\
\hline SR3-7A bottle & & 50 & & $6,632.3$ & \\
\hline SR3-11A bottle & & 50 & & 844.4 & \\
\hline
\end{tabular}

${ }^{a}$ Sorbent moisture content was $16.64 \%$. 
Table A- 2. Multi-weight sorption isotherm for Ionac SR-4, by Sybron Chemicals, Inc.

\begin{tabular}{|c|c|c|c|c|c|}
\hline Sample bottle & $\begin{array}{l}\text { Dry sorbent } \\
\text { weighta } \\
\text { (g) }\end{array}$ & $\begin{array}{l}\text { Liquid volume } \\
\text { (mL) }\end{array}$ & $\begin{array}{l}\text { Mercury spike } \\
\text { (ng/L) }\end{array}$ & $\begin{array}{l}\text { Equilibrium } \\
\text { concentration } \\
\text { (ng/L)gross }\end{array}$ & $\begin{array}{c}\text { Equilibrium } \\
\text { concentration } \\
\text { (ngh) net }\end{array}$ \\
\hline$\overline{S R 4-1 B}$ & 0.1778 & 150.45 & 83,436 & 113 & 111.72 \\
\hline SR42B & 0.3545 & 156.85 & 80,157 & 65.6 & 64.32 \\
\hline SR4-3B & 0.3562 & 155.74 & 80,853 & 67.8 & 66.52 \\
\hline SR4-4B & 0.3547 & 153.47 & 333,464 & 181 & 179.72 \\
\hline SR4-5B & 1.7748 & 154.25 & 80,797 & 2.09 & 0.81 \\
\hline SR46B & 3.5476 & 154.28 & 81,044 & 2.29 & 1.01 \\
\hline SR4-7B & 0 & 148.70 & 84,149 & 77,900 & $77,898.72$ \\
\hline SR4-8B & 0 & 146.38 & 0 & 1.28 & 0 \\
\hline SR4-9A & 0 & 150 & 0 & 754 & 752.72 \\
\hline SR4-10B & 0.1771 & 151.33 & 0 & 8.86 & 7.58 \\
\hline SR4-11B & 0.3549 & 146.92 & 0 & 5.98 & 4.7 \\
\hline \multicolumn{4}{|l|}{ SR4-9A duplicate } & 750 & 748.7 \\
\hline \multicolumn{4}{|c|}{ SR4-9A spike $(2,000 \mathrm{ng} / \mathrm{Hg}$ added) } & 2,030 & $2,028.7$ \\
\hline \multicolumn{4}{|c|}{ SR4-9A spike duplicate $(2,000 \mathrm{ng} \Lambda \mathrm{Hg}$ added) } & 1,982 & $1,980.7$ \\
\hline SR4-2A bottle wash & & 50 & & 3,740 & \\
\hline SR4-7A bottle wash & & 50 & & 12,900 & \\
\hline SR4-11A bottle wash & & 50 & & 828 & \\
\hline
\end{tabular}

${ }^{a}$ Sorbent moisture content was $26.85 \%$. 
Table A- 3. Multi-weight sorption isotherm for Keyle:X, by SolmeteX

\begin{tabular}{|c|c|c|c|c|c|}
\hline Sample bottle & $\begin{array}{l}\text { Dry sorbent } \\
\text { weighte } \\
\text { (g) }\end{array}$ & $\begin{array}{l}\text { Liquid volume } \\
\qquad(\mathrm{mL})\end{array}$ & $\begin{array}{l}\text { Mercury spike } \\
\text { (ng/L) }\end{array}$ & $\begin{array}{c}\text { Equilibrium } \\
\text { concentration } \\
\text { (ng/L)gross }\end{array}$ & $\begin{array}{l}\text { Equilibrium } \\
\text { concentration } \\
\text { (ng/) })_{\text {net }}\end{array}$ \\
\hline $\mathrm{KX}-1 \mathrm{~B}$ & 0.1035 & 150.38 & 83,661 & 274.5 & 272.6 \\
\hline$K X-2 B$ & 0.2078 & 157.17 & 80,388 & 248.7 & 246.8 \\
\hline$K X-3 B$ & 0.2074 & 156.18 & 81,471 & 126.7 & 124.8 \\
\hline$K X-4 B$ & 0.2079 & 153.77 & 333,726 & 1012 & 1010.1 \\
\hline$K X-5 B$ & 1.0386 & 154.70 & 81,479 & 40.74 & 38.87 \\
\hline$K X-6 B$ & 2.0777 & 153.89 & 83,312 & 17.74 & 15.87 \\
\hline KX-7B & 0 & 148.54 & 84,234 & 74,544 & 74,542 \\
\hline$K X-8 B$ & 0 & 146.83 & 0 & 1.87 & 0 \\
\hline$K X-9 A$ & 0 & 150 & 0 & 793.1 & 791.2 \\
\hline$K X-10 B$ & 0.1039 & 152.21 & 0 & 9.22 & 7.4 \\
\hline$K X-11 B$ & 0.2081 & 147.16 & 0 & 7.83 & 5.96 \\
\hline \multicolumn{4}{|l|}{ KX-7B duplicate } & 7,2554 & $72,552.1$ \\
\hline \multicolumn{4}{|c|}{ KX-7B spike $(202,020 \mathrm{ng} / \mathrm{Hg}$ added) } & 281,499 & $281,497.1$ \\
\hline \multicolumn{4}{|c|}{ KX-7B spike duplicate $(202,020 \mathrm{ng} \Omega \mathrm{Hg}$ added) } & 282,693 & $282,691.1$ \\
\hline KX-2A bottle wash & & 50 & & 13,504 & \\
\hline KX-7A bottle wash & & 50 & & $7,693.1$ & \\
\hline $\mathrm{KX}-11 \mathrm{~A}$ bottle wash & & 50 & & 267.8 & \\
\hline
\end{tabular}

${ }^{a}$ Sorbent moisture content was $53.83 \%$. 
Table A- 4. Multi-weight sorption isotherm for the Forager Sponge, by Dynaphor, Inc.

\begin{tabular}{|c|c|c|c|c|c|}
\hline Sample bottle & $\begin{array}{l}\text { Dry sorbent } \\
\text { weighte } \\
\text { (g) }\end{array}$ & $\begin{array}{l}\text { Liquid volume } \\
\text { (mL) }\end{array}$ & $\begin{array}{l}\text { Mercury spike } \\
\text { (ngh) }\end{array}$ & $\begin{array}{l}\text { Equilibrium } \\
\text { concentration } \\
\text { (ng/L)gross }\end{array}$ & $\begin{array}{c}\text { Equilibrium } \\
\text { concentration } \\
\text { (ng/ } /)_{\text {net }}\end{array}$ \\
\hline$\overline{\text { Spg-1B }}$ & 0.0292 & 316.23 & 46,549 & 40619 & $40,617.6$ \\
\hline Spg-2B & 0.0588 & 319.72 & 45,996 & 37674 & $37,672.6$ \\
\hline Spg-3B & 0.0584 & 318.15 & 49,357 & 39811 & $39,809.6$ \\
\hline Spg-4B & 0.0593 & 317.59 & 170,213 & 139,878 & $139,876.6$ \\
\hline Spg-5B & 0.2932 & 320.10 & 45,319 & 27,246 & $2,7244.59$ \\
\hline Spg-6B & 0.5889 & 320.41 & 46,776 & 24,488 & $24,486.59$ \\
\hline Spg-7B & 0 & 317.41 & 47,557 & 47,480 & 47479 \\
\hline Spg-8B & 0 & 150 & 0 & 1.41 & 0 \\
\hline Spg-9A & 0 & 150 & 0 & 805 & 803.6 \\
\hline Spg-10B & 0.0296 & 322.14 & 0 & 509.3 & 507.9 \\
\hline Spg-11B & 0.0589 & 317.22 & 0 & 596.9 & 595.49 \\
\hline \multicolumn{4}{|l|}{ Spg-9A duplicate } & 801.1 & 799.7 \\
\hline \multicolumn{4}{|c|}{ Spg-9A spike $(2,020.2 \mathrm{ng} / \mathrm{Lg}$ added) } & $2,874.6$ & $2,873.2$ \\
\hline \multicolumn{4}{|c|}{ Spg-9A spike duplicate $(2,020.2 \mathrm{ng} / \mathrm{Hg}$ added $)$} & $2,902.5$ & $2,901.1$ \\
\hline Spg-2A bottle wash & & 50 & & $1,636.9$ & \\
\hline Spg-7A bottle wash & & 50 & & $7,084.1$ & \\
\hline Spg-11A bottle wash & & 50 & & 366.1 & \\
\hline
\end{tabular}

${ }^{a}$ Sorbent moisture content was $53.83 \%$. 
Table A- 5. Multi-weight sorption isotherm for Mersorb $1.5 \mathrm{~mm}$ by, Nucon International, Inc.

\begin{tabular}{|c|c|c|c|c|c|}
\hline Sample bottle & $\begin{array}{l}\text { Dry sorbent } \\
\text { weight } \\
\text { (g) }\end{array}$ & $\begin{array}{l}\text { Liquid volume } \\
\text { (mL) }\end{array}$ & $\begin{array}{l}\text { Mercury spike } \\
\text { (ng/L) }\end{array}$ & $\begin{array}{l}\text { Equilibrium } \\
\text { concentration } \\
\text { (ng/L) gross }\end{array}$ & $\begin{array}{l}\text { Equilibrium } \\
\text { concentration } \\
(\mathrm{ng} /)_{\text {net }}\end{array}$ \\
\hline MS-1B & 0.2428 & 139.10 & 89432 & 914 & 913.2 \\
\hline MS-2B & 0.4372 & 130.20 & 95545 & 424 & 423.2 \\
\hline MS-3B & 0.4417 & 130.50 & 95326 & 392 & 391.2 \\
\hline MS-4B & 0.4385 & 134.60 & 367831 & 735 & 734.2 \\
\hline MS-5B & 2.1808 & 132.90 & 93604 & 2.97 & 2.19 \\
\hline MS-6B & 4.3547 & 139.10 & 89432 & 1.81 & 1.03 \\
\hline MS-7B & 0 & 139.90 & 88921 & 74081 & 74080 \\
\hline MS-8B & 0 & 150 & 0 & 0.78 & 0 \\
\hline MS-9A & 0 & 150 & 0 & 713 & 712.2 \\
\hline MS-10B & 0.2468 & 141.00 & 0 & 7.05 & 6.3 \\
\hline MS-11B & 0.4411 & 146.10 & 0 & 4.67 & 3.89 \\
\hline \multicolumn{4}{|c|}{ MS-9A spike (2020 ng $L \mathrm{Hg}$ added) } & 2143 & 2142.2 \\
\hline \multicolumn{4}{|c|}{ MS-9A spike duplicate (2020 ng/ $\mathrm{Hg}$ added) } & 2136 & 2135.2 \\
\hline MS-2A bottle wash & & 50 & & 111280 & \\
\hline MS-7A bottle wash & & 50 & & 2497 & \\
\hline MS-11A bottle wash & & 50 & & 382 & \\
\hline
\end{tabular}

${ }^{a}$ Sorbent moisture content was $3 \%$. 



\section{INTERNAL DISTRIBUTION}

1-3. D. A. Bostick

4. T. B. Conley

5. J. F. Hensley

6. D. A. Hutchins

7-9. K. T. Klasson
10. S. M. Robinson

11. P. A. Taylor

12. Central Research Library

13. Laboratory Records, RC

14-15. Laboratory Records, for OSTI

\section{EXTERNAL DISTRIBUTION}

16. Becky Sams, Lockwood Greene Technologies, 125 Broadway, Oak Ridge, TN 37830

17. M. J. Connolly, Lockheed Martin Idaho Technologies Company, P.O. Box 1625, Idaho Falls, ID 83415-3875

18. D. Gombert, Lockheed Martin Idaho Technologies Company, P.O. Box 1625, Idaho Falls, ID 83415-3875

19. H. Holmes Burns, 3702 Wexford Place South, Martinez, GA 30907

20. G. A. Hulet, Lockheed Martin Idaho Technologies Company, P.O. Box 1625, Idaho Falls, ID 83415-3875

21. W. A. Owca, U.S. Department of Energy, MS-1225, 850 Energy Drive, Idaho Falls, ID 83401-1563

22. J. Petersell, AIMS, Inc., 5470 Ward Road, Suite 370, Arvada, CO 80002

23. L. Schwendiman, Lockheed Martin Idaho Technologies Company, P.O. Box 1625, Idaho Falls, ID 83415-8102 